\title{
Challenges and mechanisms of teachers in the implementation of modular distance learning in the Philippines: a phenomenological study
}

Desafíos y mecanismos de los docentes en la implementación del aprendizaje a distancia modular en Filipinas: un estudio fenomenológico

Desafios e mecanismos dos professores na implementação do ensino à distância modular nas Filipinas: um estudo fenomenológico

Jimmy Rey O. Cabardo, LPT, MAEd

jimmyrey.phd@outlook.com ; jimmyrey.cabardo@deped.gov.ph Hagonoy National High School, Guihing, Hagonoy, Davao del Sur https://orcid.org/0000-0002-1219-0580

Cristy Jean O. Cabardo, LPT cristyjean.cabardo@depeed.gov.ph Sacub National High School, Sacub, Hagonoy, Davao del Sur

\section{Sheila Jean O. Cabardo-Mabida, LPT}

jeanzcabz18@gmail.com Lapulabao National High School, Lapulabao, Hagonoy, Davao del Sur

\begin{abstract}
COVID-19 pandemic brought so many changes in the state of education after school's temporary closure. Educational institutions transitioned to modular distance learning from the usual face-to-face teaching which put both teachers and students less prepared, if not totally unprepared. This qualitative phenomenological study explored the challenges and mechanisms of teachers in the implementation of modular distance learning in the Philippines amidst COVID-19 pandemic. Data were gathered through in-depth interview to twelve (12) teachers, six (6) were teaching in the elementary, and the other six (6) teaching in the secondary level. Recorded interviews were transcribed and analyzed using the following steps: data reduction, data display, and conclusion drawing and verification. Ethical issues were considered in the conduct of the study. Results revealed that the challenges of teachers in modular distance learning includes time-consuming, incomplete and unanswered modules, inadequate parental support, and insufficient trainings to teachers. The mechanisms utilized by teachers to overcome the challenges includes time management, regular communication to parents and students, reskilling and upskilling of teachers, and utilization of blended learning. With this, it is recommended that DepEd should continue to undertake monitoring and evaluation on the implemented modular distance learning to assess its quality and relevance on the current status of education in the country.
\end{abstract}

Keywords: Education and Teaching, Modular Distance Learning, Experiences of Teachers, Phenomenological Research, Philippines

\section{RESUMEN}

La pandemia de COVID-19 trajo muchos cambios en el estado de la educación después del cierre temporal de la escuela. Las instituciones educativas hicieron la transición al aprendizaje a distancia modular de la enseñanza presencial habitual, lo que puso tanto a los profesores como a los estudiantes menos preparados, si no totalmente desprevenidos. Este estudio fenomenológico cualitativo exploró los desafíos y mecanismos de los maestros en la implementación del aprendizaje a distancia modular en Filipinas en medio de la pandemia de COVID-19. Los datos fueron recolectados a través de entrevistas en profundidad a doce (12) maestros, seis (6) estaban enseñando en la primaria y los otros seis (6) enseñando en el nivel secundario. Las entrevistas grabadas se transcribieron y analizaron siguiendo los siguientes pasos: reducción de datos, visualización de datos y elaboración y verificación de conclusiones. Se consideraron cuestiones éticas en la realización del estudio. Los resultados revelaron que los desafíos de los maestros en el aprendizaje modular a distancia incluyen módulos que consumen mucho tiempo, están incompletos y sin respuesta, un apoyo de los padres inadecuado y una capacitación insuficiente para los maestros. Los mecanismos utilizados por los maestros para superar los desafíos incluyen: administración del tiempo, comunicación regular con los padres y estudiantes, actualización y mejora de las habilidades de los maestros y utilización del aprendizaje combinado. Con esto, se recomienda que el DepEd continúe con el seguimiento y la evaluación de la educación a distancia modular implementada para evaluar su calidad y relevancia sobre el estado actual de la educación en el país. 
Palabras clave: Educación y enseñanza, aprendizaje a distancia modular, experiencias de profesores, investigación fenomenológica, Filipinas

\section{RESUMO}

A pandemia COVID-19 trouxe muitas mudanças no estado da educação após o fechamento temporário da escola. As instituições de ensino fizeram a transição do ensino presencial para o ensino modular à distância, o que deixou professores e alunos menos preparados, senão totalmente despreparados. Este estudo fenomenológico qualitativo explorou os desafios e mecanismos dos professores na implementação do ensino à distância modular nas Filipinas em meio à pandemia de COVID-19. Os dados foram coletados por meio de entrevista em profundidade a doze (12) professores, seis (6) lecionavam no ensino fundamental e os outros seis (6) lecionavam no ensino médio. As entrevistas gravadas foram transcritas e analisadas nas seguintes etapas: redução dos dados, exibição dos dados e desenho e verificação da conclusão. Questões éticas foram consideradas na condução do estudo. Os resultados revelaram que os desafios dos professores no ensino a distância modular incluem módulos demorados, incompletos e sem resposta, apoio parental inadequado e treinamentos insuficientes para os professores. Os mecanismos utilizados pelos professores para superar os desafios incluem: gerenciamento do tempo, comunicação regular com pais e alunos, requalificação e qualificação dos professores e utilização da aprendizagem combinada. Com isso, recomenda-se que o DepEd continue realizando o monitoramento e a avaliação da modalidade ead modular implantada para avaliar sua qualidade e relevância na situação atual da educação no país.

Palavras-chave: Educação e Ensino, Ensino à Distância Modular, Experiências de Professores, Pesquisa Fenomenológica, Filipinas

\section{INTRODUCTION}

In January 2020, the World Health Organization (WHO) declared the outbreak of Coronavirus disease 2019 (COVID-19) as a public health emergency of international concern which resulted in the closure of schools sometimes of March 2020 affecting 91 percent of students globally. With the continuing rise of confirmed cases and in consideration of the significance of education despite the pandemic, government around the world resorted to learning continuity plan and utilized learning modalities that will not expose the learners to the threat of the pandemic but will allow them to continue learning despite the existence of the threat.

Aside from that, the pandemic has also resulted in the extensive disturbance such as travel restrictions and imposition of community quarantines and border control (Chinazzi et al., 2020), global economic recession (Fernandes, 2020), political disputes (Barrios \& Hochberg, 2020), racism (Habibi et al., 2020), and misinformation, controversies and increase circulation of fake news (Enitan et al., 2020). One of the most affected is the educational sectors (Tria, 2020; Viner, et al., 2020).

United Nations (2020) mentioned that disruptions to instructional time in the classroom can have a severe impact on a child's ability to learn. The longer marginalized children are out of school, the less likely they are to return. Children from the poorest households are already almost five times more likely to be out of primary school than those from the richest. Being out of school also increases the risk of teenage pregnancy, sexual exploitation, child marriage, violence and other threats. Further, prolonged closures disrupt essential school-based services such as immunization, school feeding, and mental health and psychosocial support, and can cause stress and anxiety due to the loss of peer interaction and disrupted routines (Baloran, 2020; Henaku, 2020; World Health Organization, 2020b).

In the Philippines, going back to school during this pandemic poses a challenge for all - the school head, teachers, non-teaching personnel, parents, learners and the broader community. But no matter how challenging the times may be, it is always necessary to make education equally important with the health safety of the learners as top priorities (Department of Education, 2020a). In its pursuit to uphold this right, the Department of Education (DepEd) ensures the learning continuity of learners amid the COVID-19 pandemic through the issuance of DepEd Order No. 12, 
s. 2020 or the "Adoption of the Basic Education Learning Continuity Plan for School Year 20202021 in the Light of the COVID-19 Public Health Emergency" (Department of Education, 2020b). Under the BE-LCP, new ways of teaching will be embraced specifically on distance learning delivery modalities such as modular instruction, online learning, and TV/radio-based instruction. All of which needs new knowledge, skills and attitudes to be realized (Tria, 2020). As such, most of the schools nationwide particularly Region XI selected the modular instruction as a default modality in delivering education to students remotely. With modular instruction, group of teachers within the division were tasked to write self-learning modules (SLMs) to be distributed to schools while teachers were to developed weekly home learning plan which will be distributed along with the SLMs to serve as guide to parents for the self-paced learning of their students (Department of Education, 2020c).

However, several challenges were encountered by teachers and clamors were heard from the fields especially on the distribution, retrieval, monitoring and evaluation aspects of utilizing modular instruction. Likewise, many of the parents of the learners are unable to read and write, or if they could, some are unable to understand the lessons because some of the educated parents only finished high schools. Aside from that, teachers were unable to check the modules on time and consequently unable to provide timely feedback on learner's progress and achievement due to the need to reproduce SLMs for distribution. With these realities, the researcher would like to explore the challenges and mechanisms of teachers in the implementation of modular distance learning in selected schools in the Philippines amidst COVID-19 pandemic using qualitative phenomenological research design. With the outcomes of the study, the researcher may be able to offer viable solutions that may be shared along with other schools experiencing the same predicaments. The results may be utilized as inputs for policy making or revisiting available policies and guidelines related to modular distance learning as well as for developing possible program interventions and solutions to the impending problems in distance learning modality.

\section{Purpose of the Study}

The main purpose of this qualitative phenomenological study was to explore the underlying themes depicting the challenges and mechanisms of teachers in the implementation of modular distance learning in selected schools in the Division of Davao del Sur, Philippines for the School Year 2020-2021. This study sought answers to the following research questions:

1. What are the challenges encountered by teachers in the implementation of modular distance learning?

2. How does teacher overcome the challenges encountered in the implementation of modular distance learning?

\section{THEORETICAL UNDERPINNINGS}

This study is primarily anchored on Moore's Transactional Distance theory. Moore (1983) developed this theory of distance learning programs to investigate two variables: students' autonomy and the distance between students and teachers. The theory mainly describes the learner and the educator/teacher relationship. The transactional distance is essential, according to Moore's understanding, because the perception is grounded in distance learning within a social structure, not in its traditional form. The second element of Moore's theory involves the autonomy of the student, as the distance between him and his teacher means that the student must adopt responsibility for his own learning (Abuhassna \& Yahaya, 2018; Hanson et al., 1997).

As applied in the modular instruction, the transactional distance occurred between the students and teachers as the self-learning modules allow them to learn despite the geographical location between them. In this manner, students developed independence and responsibility in one's 
learning. Despite the transaction distance, learners still interact since interaction may occur between students and teachers, students and students, and students and materials. Interaction played an important role in maintaining learner's momentum in learning towards the material.

Moreover, this study is also premised from the Theory of Constructivism. Lee and Lin (2009) argued that the chief responsibility of the learners is to construct one's understanding based on how they make meanings and essences on the different experiences provided by the teachers and the environment. From the constructivist's point of view, the teachers are merely facilitators of learning, and the learners are the one responsible for their learning. When applied in modular instruction, teachers provide learning experiences to the learners in the form of self-learning modules. The interaction that will happen between the learner and the material, and the learner and teacher will be the determining factor in building learner's understanding. In the same manner, the theory reminded teachers that although learning is the sole responsibility of the learners, teachers should provide various experiences to them, and facilitate effectively in the process of meaningmaking.

\section{METHODS}

This part presents the research design, research participants, data collection, data analysis, role of the researcher, and ethical consideration.

\subsection{Research Design}

Qualitative phenomenological design was used in this study. As posited by Almeida et al. (2016), qualitative research deals with understanding human behavior in nature because it studies human behavior and the reasons that govern it. It captures individual's meanings, definitions, and descriptions of events.

Under this design, the researcher used phenomenological research tradition to explore the underlying themes depicting the challenges and mechanisms of teachers in the implementation of modular distance learning. According to Langdridge (2007), phenomenological method aimed to reveal the implication of an individual's experience of a specified phenomenon through concentrating on a tangible realistic account grounded in everyday life. Creswell and Plano Clark (2007) averred that this research design is founded on the concept of inquiry, one may move past awareness of things, experiences or understanding to arrive at the very essence of the thing itself or the phenomenon. Groenewald (2004) and Hammersley (2003) mentioned that in phenomenological research, the researcher cannot be detached from his/her own presuppositions and that the researcher should not pretend otherwise. Yüksel and Yıldırım (2015) argued that the general purpose of the phenomenological study is to understand and describe a specific phenomenon indepth and reach at the essence of participant's lived experience of the phenomenon. Becker (1992) and, Morrissey and Higgs (2006) emphasized that most phenomenologists do not view human experience as an undependable source of data; rather they see it as the foundation of knowledge about human phenomena. For them, everyday world is a valuable and productive source of knowledge, and that one can learn much about peoples' lived experiences and reap key insights into the nature of an event by analyzing how it occurs in our daily lives and its implication to research. Hence, this qualitative research tradition was utilized.

\subsection{Research Participants}

The participants in the study were determined using purposive sampling. Fraenkel, Wallen and Hyun (2013) described purposive sampling as a sampling method based on previous knowledge of a population and the specific purpose of the research where the researcher uses personal judgment to select a sample. Boyd (2001) mentioned that for a phenomenological study, it regards two to 10 participants or research subjects as adequate and sufficient to reach theoretical saturation, 
while Creswell (2018) recommended long interviews with up to 15 individuals to gather the needed information and to undergo data analysis.

For the purpose of theoretical saturation, twelve (12) teachers were interviewed which is composed of six (6) teachers coming from the elementary, and another six (6) teachers coming from the secondary level were selected as participants. These teachers must be classroom advisers, teaching at least three (3) years regardless of gender preferences and teaching position, and willing to participate in the study.

\subsection{Data Collection}

Primary data were gathered based on the narrative experiences of teachers. An interview guide was used since it lists possible questions that may uncover the necessary information needed by the researchers during the in-depth interview. Instead of the face-to-face interview, the researcher utilized online interview by sending the interview questions through private message. This was done to avoid possible personal contact with other due to the continuing threat of COVID19. The researcher did not include each participant's addresses or schools to preserve their privacy, although, they are pointing general locations.

\subsection{Data Analysis}

The data on the challenges and mechanisms of teachers in the implementation of modular distance learning in the Philippines amidst COVID-19 pandemic were analyzed using thematic analysis. As stressed by Braun and Clarke (2006), thematic analysis is a method used to find and analyze emerging themes in a dataset to unravel the themes, meanings and essences of the experiences of an individual.

In the thematic analysis, the following steps were followed: (1) transcribing data from digital recorder and from field notes, (2) making meaning-based translation from the vernacular language to the English language, (3) identifying the significant statements in the transcript interview; (4) generating codes, (5) highlighting key phrases, and (6) defining and naming themes to cohere around a central idea. The results were presented back to the participants for comments and validation. Adjustments were done, based on the comments and suggestions of the participants.

\subsection{Role of the Researcher}

In the conduct of the study, the researcher did all the necessary things that needs to be done. When there is a need to write the manuscript, the researcher served as the writer; when there is a need to gather the data through interview, then the researcher served as the interviewer; when there is a need to check and review the overall research manuscript, then the researcher taken the role of an editor and a grammarian; and when the researcher need to transcribe, translate and analyze the results of the study, then the researcher will take the role of a transcriber, translator, and analyzer in the results.

\subsection{Ethical Considerations}

In this study, the researcher observed the proper protocol in conducting the study by asking permission from the Schools Division Superintendent (SDS) for the conduct of the study in selected elementary and secondary schools in the Division of Davao del Sur. Then, same permission was secured from respective Public Schools District Supervisor (PSDS) or District Principal In-Charge per school district and to the different elementary and secondary school heads attaching the approved permission from the Schools Division Superintendent. 
After the conduct of the study and transcription of data, a copy of the IDI records was given to each informant and participant to allow them to give their comments and suggestions. After which, the researcher verbally asked permission from the participants to allow him to use the transcripts for the analysis. Also, to address ethical issues, the researcher assigned pseudonyms with corresponding ID to each informant and participant of the study to ensure anonymity and confidentiality. This is following the most significant standard in conducting research as posited by Berg (2009) who stated that researchers must do no harm to their respondents. Though their responses were recorded and audiotaped, the researcher ensured that all the data that were collected from this study were dealt with utmost respect and confidentiality and were reported under aliases or pseudonyms with a general reference when presented at meetings and conferences or published in journals. Under no circumstances that this research divulged the individual or collective identities of the informants of the study as this may constitute violation in the ethics of research. The issues on anonymity and confidentiality were also discussed in the Informed Consent Form signed by the participants prior to the conduct of the interview. This study does not have any conflict of interest known by the authors.

\section{RESULTS AND DISCUSSION}

This study aimed to explore the challenges and mechanisms of teachers in the implementation of modular distance learning in the Philippines amidst COVID-19 pandemic. Qualitative data was gathered using semi-structured interviews. Participants described their perceptions about the implementation of modular distance learning. The following research findings are based on the perceptions of researcher participants and categorized into research questions. Figure 1 shows the emerging themes on the challenges and mechanisms of teachers in the implementation of modular distance learning.

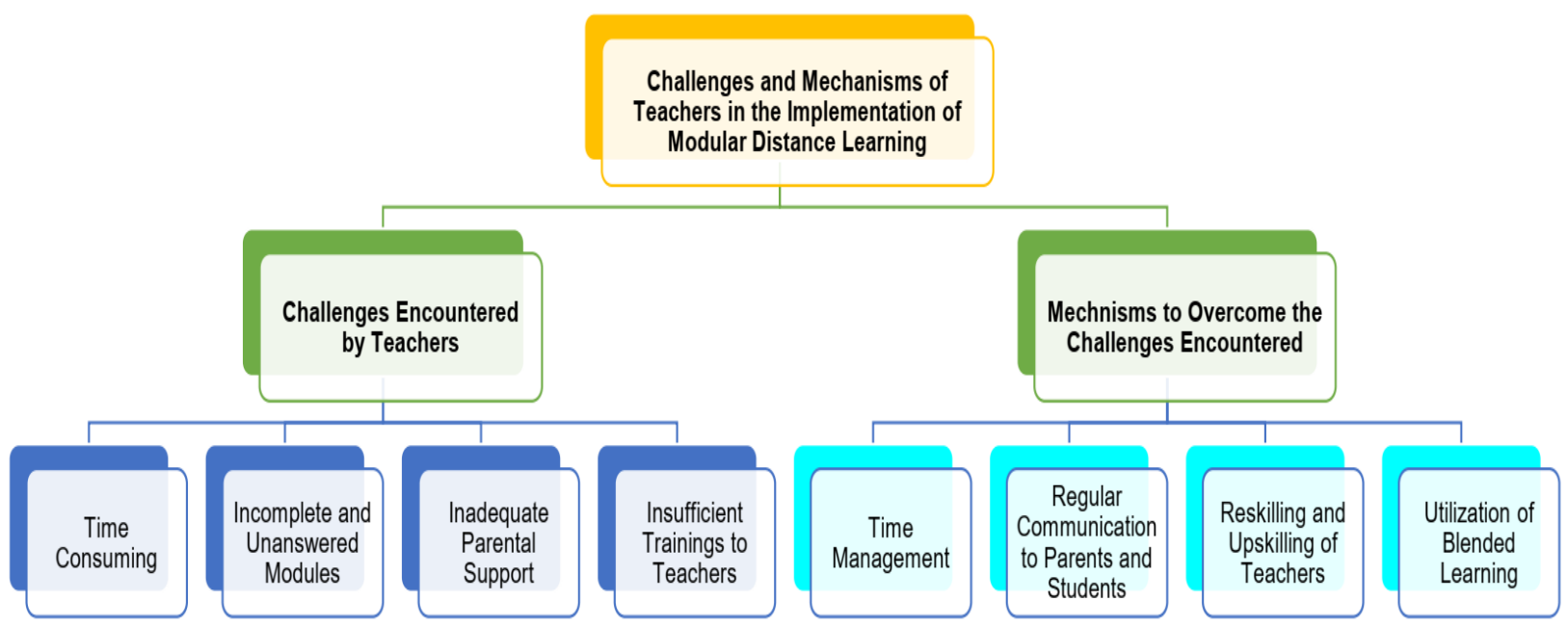

Figure 1. Emerging Themes for the Challenges and Mechanisms of Teachers in the Implementation of Modular Distance Learning.

\subsection{Challenges in the Implementation of Modular Learning}

The unprecedented transition to distance learning modality particularly with modular learning, teachers When teachers were asked about the challenges, they have encountered in the implementation of modular distance learning in this time of pandemic, four (4) themes were generated from the validated transcribed interviews, and this is shown in Figure 1 above. These themes include: (1) time consuming; (2) incomplete and unanswered modules; (3) inadequate parental support; and (4) insufficient trainings to teachers. 
Time-Consuming. The unprecedented transition and shift to modular distance learning had placed teachers into unprepared situations making the modality as time consuming. They argued that the implementation of current modality needs ample time because of the various tasks that need to be accomplished. For instance, they need to edit the modules, then print it, and then sort. After sorting, it will be distributed to the parents who will get the modules. In fact, there are teachers that thought that the modules to be given to the learners are centrally prepared and will only be distributed by teachers. However, during the implementation of modular learning, teachers are bombarded with the task of reproducing the modules which may sometimes exhaust all their patience and perseverance especially when there are mechanical problems that were encountered during the reproduction of the materials. Here are some of the experiences personally shared by some teachers:

"The current implementation of modular distance learning is really exhausting and time-consuming. As teachers, I need to prepare the materials then edit it, after that it will be reproduced and sorted and stapled for distribution. These tasks are additional burden to teachers”. - Q1P3

"...during the actual implementation, teachers were bombarded by so many tasks of editing the materials, reproducing it, sorting and stapling it. After that, we distributed it to parents and then the materials were retrieved. My time was consumed from that process alone and that, I am already exhausted when checking the returned SLMs". - Q1P6

"The use of modular distance learning modality is time-consuming on my part because I have to edit the modules, and then reproduce it, and distribute and retrieve it. It really exhausts my time leaving me tired when checking the returned modules, but I don't have choice since we need to ensure safe education in this time of pandemic". - Q1P9

The study of Yarovaya et al. (2020) revealed that with distance learning modality, teachers need to dedicate most of their time in crafting instructional materials and learning experiences that the students need to work independently. They mentioned that remote instruction is time-consuming when it comes to lesson preparation especially when one need to ensure better participation among the learners. Aside from preparation, teachers also need to double check the works of the learners whether they are the one answering their work or are they cheating or used other facilities to answer their lessons - things that adds to teacher's burden with distance learning modality.

Incomplete and Unanswered Modules. With modular distance learning, the returned SLMs and their summative tests were considered the primary sources of information on their level of understanding and learning. Other sources of learner's performance were from their performances and outputs which were submitted online or through their parents and guardians. However, during the conduct of the interview, teachers were amenable that there were many students who returned incomplete and unanswered modules. While the modules were not the primary source for learner's grade, however the activities and exercises in the modules served as their practices towards learning the competencies better. Returning incomplete and unanswered modules may hinder the overall understanding and development of the learners in a given competency since the exercises and activities were the formative assessments for modular instruction. Formative assessments were crucial in the foundation of learning and eventual understanding of students, since understanding is built from the series of learning experiences provided by the teachers. Here are some of the personal narrations shared by teachers:

"As a teacher, I really find it challenging seeing lots of my students returning incomplete and unanswered modules. I spent so much time editing the modules and reproducing it and making sure that the learning experiences may give them foundation for the competency I am teaching”. - Q1P1

"When the students returned unanswered modules since I am doubtful whether their learning is authentic or not because they were not able to answer the activities and exercises in the SLMs". - Q1P4 
"The main challenge I met with this modular distance learning was when students returned their learning modules without answers or with incomplete answers in the exercises and activities". - Q1P12

This theme is consistent with the findings of Jayani (2021) when he found that that one of the challenges of modular distance learning is beating the deadline set by the school. He argued that there are students who submitted their learning modules late because they cannot finish on time the bulk of modules given to them. Hence, Reimers and Schleicher (2020) stressed that need to revisit and re-prioritize the curriculum goals and to strike out the competencies which are not responsive to the current needs of the learners and those that would bring a disruptive impact to the distance learning modality being utilized. This was necessary to ensure that learners would be able to answer their learning modules on time and be able to submit it on time. Aside from that, other competencies that were found to be inappropriate in this time would just cause learner's difficulty in answering the modules and returning it without any answers.

Inadequate Parental Support. During the implementation of distance learning modalities, DepEd issued Memorandum No. DM-CI-2020-00162 dated July 21, 2020, where DepEd Undersecretary San Antonio highlighted the important role of parents in the effective implementation and utilization of distance learning in this challenging time. In fact, several parents' assemblies and consultation and virtual meetings were conducted to inform and disseminate the crucial roles in the current modality of education. However, teachers argued that there was an inadequate parental support extended by parents to their children's education. Teachers highlighted that most of their parents were workers, and therefore spent lesser time helping and assisting their children's education. Aside from that, there were also illiterate parents who cannot assist their children in their modules nor help them with in serving as instructional coach due to limited knowledge and skills. In addition, teachers also heard the parents arguing the additional burden in their shoulders with this modular distance learning. Some of the personal experiences of teachers were shared below:

"The most challenging part of this modular distance learning was the inadequate support given by parents to their children. Most of the parents in my class were laborers and they really need to work to earn for their daily living and basic consumption leaving their children unattended". - Q1P5

"Some of my parents were illiterate and therefore cannot be expected to assist their children in their learning modules. There were parents who were patient in managing the time of their children answering the modules but then again, they cannot help them whether the answers were correct or not because of the limited knowledge". - Q1P10

"Support from parents matters a lot for me particularly that the current approach in teaching was some sort of homeschooling. Inadequate support from parents was really my primary challenge with this modular distance learning ”. - Q1P11

In Memorandum No. DM-CI-2020-00162 dated July 21, 2020, DepEd Undersecretary San Antonio identified the suggested strategies in the implementation of distance learning delivery modalities for SY 2020-2021. Under the said issuance, the guidelines and general considerations in using various distance learning delivery modalities were presented. For instance, under the modular distance learning, DepEd stressed the importance of the support of family members and community who are trained as learning facilitators to provide the necessary instructional support to the leaners as well as constant communication between parents and teachers to track and monitor their performance. San Jose et al. (2021) emphasized that because of COVID-19 pandemic, parents need to extend their maximum support to their learners especially in answering there learning modules. Without parental support, learners will surely find modular instruction to be difficult.

Insufficient Trainings to Teachers. With the sudden shift to distance learning modality provides gaps on the knowledge, skills and competence of teachers on the use of such modality in the teaching and learning leading teachers to feel its implementation difficult and challenging. Since 
the inception of COVID-19 pandemic and the need for learning continuity, trainings were conducted to teachers, school heads and parents. However, teachers argued that the trainings they received were insufficient to prepare them to become effective teachers utilizing distance learning modality. In fact, some teachers believed that because the modality is new, teachers were in the period of adjustments and thus, several trainings and capacity building activities should be conducted to provide the best possible experiences to teachers. Here are some of the personal experiences shared by teachers during the interview:

"Trainings and capacity building activities related to distance learning were provided to us. However, there was insufficient training among teachers on the use of distance learning hence, I find the distance learning modality difficult. Aside from that, most of the trainings were offered online which again added another difficulty particularly in gaining new skills”. - Q1P2

"Teacher should be capacitated prior to the utilization of distance learning. Yes, trainings were conducted, and orientation were given to us but still, its insufficient to really provide better learning experiences to my students particularly with modular distance learning ". -Q1P8

Capacitating teachers is one of the ways to make distance learning successful. When the teachers do not have enough knowledge and skills in teaching through distance learning, they cannot effectively use the modality to provide better learning experiences to the students. Rasmitadila et al. (2020) mentioned that the basic barrier challenging the effective utilization of distance learning modality is technical barrier which includes teacher's capacity to use the modality in teaching and learning. Borup and Evmenova (2019) stated that knowledge, skills, attitudes, and tendencies are the things important in becoming a better school. This means that when teachers are knowledgeable enough and were strongly trained, they would be able to help the learners in their study in this time of COVID-19 pandemic.

\section{Mechanisms in Overcoming the Challenges}

Since the inception of COVID-19 pandemic, schools nationwide shifted to distance learning modalities particularly the use of modular distance learning to warrant learning continue amidst the overwhelming cases brought by the pandemic. Because of this unprecedented change, teachers were confronted with various challenges and difficulties in the implementation of $\mathrm{K}$ to 12 Basic Education Curriculum using modular distance learning. However, teachers were able to adjust and gained new perspectives and mechanisms on overcoming those challenges and difficulties. As shown in Figure 1 above, teachers were utilizing the following mechanisms to overcome the challenges they had encountered: time management, regular communication to parents and students, reskilling and upskilling of teachers, and utilization of blended learning.

Time Management. While most teachers argued that modular instruction is time consuming, they also believed that managing the time effectively would help teachers overcome the problem. They argued that printing and reproducing the modules ahead of time, then sorting it after would help teachers save time and not cram during module distribution. Aside from that, it would also help them do other tasks such as checking of learning modules and recording of scores. The works of teachers may be too much particularly with this distance learning modality, however, if they can manage their time wisely, they would be able to hurdle such difficulty and have time for personal and professional development and other activities. Some of the personal experiences of teachers were shared below:

"I believe that the secret of being confronted with cram and hectic schedule is really to manage the time wisely and effectively. When I say wisely and effectively it means to prioritize things. Those that needs urgent attention should be given urgency and let other things be done when I am have my available time. You know, if we want, we can really find time. It's just a matter of practice and consistency. Time management should be our habit.". - Q2P4 
"Whenever bombarded with so many activities and schedule especially with module reproduction, sorting and distribution, I am really writing my schedule in my notebook and as much as possible I will stick with the schedule so that I will not have the chance of missing other activities. Managing my time is really important and necessary.". - Q2P9

This theme supported the claims of Heath and Shine (2021) when they mentioned that time management is a challenge for teachers conducting remote and online learning as they are in the period of adjusting and their knowledge and skills are not yet fully developed for such modality. However, they were amenable that there are techniques and methods that could be utilized in order to facilitate the effective management of time during such ordeal and can be helpful in teaching the learners through remote and online instruction.

Regular Communication to Parents and Students. Most of the teachers argued that many students submitted incomplete and unanswered learning modules which gave them difficulty in tracing their learning and their lesson pacing. With this, teachers believed that regular communication to parents and students using various modes and media could help lessen this problem, if not totally eradicate it. Many teachers also shared that their constant communication with parents and learners helped them in their lessons since they can easily provide techniques and assistance to the learners whenever they encountered difficulties. Aside from that, it also gives them the perspectives as to the current condition and status of the learners especially those who do not have parents who can constantly help them in their study, or those learners with working parents who do not have time to assist them in their modules. Here are some of the personal sharing given by the teachers during the conduct of the interview:

"For me, communication to the parents and students are really important to ensure that the learners will submit their modules on time. Aside from that, it will also help them when they encounter difficulties in answering the modules making them to answer the module and submit it completely and on time. Regular communication is really important in this time of pandemic.". Q2P1

"In my point of view, I think my constant communication to my learners because when I communicated them, I also reminded them to submit their modules completely with answers and of course it should be on time. I can also know the conditions of my students whether they have parents to assist them or are busy working for a living. With this, I may be able to help them overcome their difficulties with the modules. It's our duty to assist them because we are not in the face-to-face situation where we can easily help them.". - Q2P6

Regular and consistent communication is an important aspect of ensuring success in the implementation of distance learning modality amidst COVID-19 pandemic. Teachers need to regularly communicate to the parents and students to give them update on their pacing and lesson development. De Leon (2021) also mentioned in his research article the need for regular communication to teachers and other stakeholders in the effective implementation of modular distance learning. In fact, in an article written by Hernando-Malipot (2020) in Manila Bulletin, he stressed the important role played by parents in the current learning modalities utilized by DepEd for learning continuity. He highlighted that parent served as learning coach and facilitators to ensure the regular pacing of students as they answer their learning modules. Aside from that, he also stated that parents should communicate to teachers whenever confronted with various difficulties - lesson content, teaching pedagogy and many others, and at the same time, teachers should also communicate regularly to the parents and the learners to monitor the progress of their modules.

Reskilling and Upskilling of Teachers. One of the important aspects in realizing the Basic Education Learning Continuity Plan (BE-LCP) of DepEd is to reskill and upskill the teachers so that they will become more prepared and ready in the implementation and utilization of distance learning modality in teaching the students. Teachers shared that while trainings were conducted, they argued that the trainings they received were inadequate. However, they also stressed that giving enough trainings and capacity building activities to teachers, they would surely be able to 
provide better learning experiences to the students even with modular distance learning. Training enables teachers to be more acquainted with the process of teaching with modular instruction and prepare them to be more ready in terms of knowledge and skills in giving intervention to students when they encountered difficulties. Here are some of the narratives of teacher's experiences talking about the need for reskilling and upskilling of teachers:

"I think the difficulties we encountered will always redound to the trainings and capacity building activities we participated in preparation for the distance learning. If I myself is skilled and knowledgeable enough with modular distance, I may be able to adjust easily with the modality. That is why, more trainings should be made available for teachers.". - Q2P2

"I can say that DepEd provides us orientation and training on distance learning but its inadequate. For me, the best way to overcome these challenges is really to capacitate us, to upskill us in this kind of modality particularly on assessing and evaluating the available modules because there are modules that needs to be checked due to some errors. We should also know how to conduct quality assurance to our modules and other skills with distance learning modalities. Trainings are really important in my part especially that I am just new to my profession.". - Q2P11

The framework mentioned by Reimers and Schleicher (2020), they asserted the need to train and upskill teachers in the current modality to ensure that their pedagogical content knowledge would be responsive to the need of the learners in this new normal. Reimers et al. (2020) highlighted that the unprecedented shift to distance learning modality offers professional development to teachers in the form of capacity building activities, trainings, and seminars to enhance both their content and pedagogical knowledge given the adjustments in the competencies and change of modalities utilized in teaching and learning. The repertoire of teaching strategies that were previously learned by teachers used in the traditional face-to-face teaching may not anymore be applicable in distance learning.

Utilization of Blended Learning. Blended learning entails the utilization of other learning modalities aside from the primary modular learning. With blended learning, teachers shared that they enjoy teaching the students with modular learning combined with online instruction since the difficulties that learners encountered in their learning modules can be checked through online discussion. Aside from that, it also gives chance to learners who do not have their parents to assist them in their studies. Teachers also mentioned their happy feelings in talking and seeing their students on screen. Here are some of the personal narrations of teachers during the interview:

"For me as a teacher, I am now utilizing blended learning. While I distributed the modules to my students, I also have time giving them classes through online. With that, the difficulties of the learners and the problem on returning incomplete and unanswered modules as well as inadequate parental support can be resolved. Aside from that, I can also have time for “kumustahan” with my students.”. - Q2P7

"For me, I think teachers should not only be boxed with modular learning but rather explore other modalities to ensure effective delivery of the lessons. Yes, I am confronted with so many problems in modular instruction, but I can check them through other modalities like meeting them online and conducting classes through Google Meet. As a teacher, blended learning is really a necessity in today's time so that we can give the best possible learning experiences to the students. Aside from that, it's also good to see my students even though it's just online. ". - Q2P10

The study of Hashemi and Sina (2020) regarding the utilization of blended learning approach in teaching and learning English disclosed that it provides a positive impact in the effective integration in learning English. While they stressed that blended learning is a relatively new approach in teaching, it was found to substantially improve student's performance when being used appropriately and and correctly. Jones (2019), on the other hand saw how blended learning transformed the classrooms ingto one that can engage the learners effectively. Teachers are seen as 
facilitators of the learning which creates a significant impact to the learners as they independently learn the lessons guided and facilitated by the teachers.

\section{CONCLUSION}

This study concluded that the utilization of modular distance learning provides various challenges to teachers where they find it time-consuming with learners submitting incomplete and unanswered modules where parental support was seemed inadequate and having insufficient trainings to effectively use the learning modality in the teaching and learning. With these challenges, teachers overcame it by effectively managing their time, having regular communication to parents and students, undergo reskilling and upskilling to enhance their knowledge and skills in modular learning, and utilize blended learning.

While modular learning modality still the primary mode of learning in the country, DepEd may revisit the current standards of practices in teaching with modular learning and may enhance the standards to include the use of other modalities to provide support mechanisms to whatever constraints that the modality may bring to teaching and learning while at the same time maximizing the academic performance of the learners amidst the current educational challenges.

School heads may continue to extend their instructional support to teachers by conducting regular clinical supervision through class observation to determine the strengths and weaknesses of teachers in the delivery of learning with modular distance modality. Technical assistance and mentoring program may be provided to those teachers who were having trouble in effectively using the modality in teaching and learning and may prioritize them in sending to various capacity building and professional development activities. Likewise, they may also find other alternatives and interventions to lessen the burden of the teachers in modular instruction especially with module reproduction.

Teachers may engage to various professional development activities to improve the repertoire of their teaching skills with modular learning and may continue to nourish their relationship with the parents to ensure effective delivery of modular instruction among students. Likewise, they may encourage themselves to enroll in graduate and advanced professional studies to enhance their learning in various educational and pedagogical aspects of teaching and learning as well as with the current trends in education.

In this study, extra care should be observed when interpreting the results since the study has some limitations. First, the focus was only limited to one schools division and the number of participants may be enough to reach theoretical saturation, however, it may not be used to generalize the whole context of modular distance learning in the country as one cannot extrapolate it to all teachers in the country. Second, while the conduct of online interview is still valid and reliable way of collecting data and information, still, the researcher that it would be better to have face-to-face interview to the participants to really have personal encounter with them and at the same time be able to feel their feelings during the series of questions being asked to them. Finally, the conduct of this qualitative phenomenological research may still have some gray areas that needs to be clarified. Hence, it is recommended that future research using quantitative or mixed methods may be conducted to take advantage with the strengths and weaknesses of the results of the study and to explore other possible means of looking into the challenges and mechanisms of teachers in the implementation of modular distance learning in the country. 


\section{REFERENCES}

Abuhassna, H. \& Yahaya, N. (2018). Students' Utilization of Distance Learning through an Interventional Online Module Based on Moore Transactional Distance Theory. EURASIA Journal of Mathematics, Science and Technology Education, Vol. 14, No. 7, pp. 3043-3052. https://doi.org/10.29333/ejmste/91606.

Almeida, A.B., Gaerlan, A.A. \& Manly, N.E. (2016). Research Fundamentals from Concept to Output: A Guide for Researchers \& Thesis Writers. Quezon City: Adriana Publishing Corporation, Incorporated.

Baloran, E.T. (2020). Knowledge, Attitudes, Anxiety, and Coping Strategies of Students during COVID-19 Pandemic, Journal of Loss and Trauma, Vol. 25, No. 8, pp. 635-642, DOI: https://doi.org/10.1080/15325024.2020.1769300.

Barrios, J.M., \& Hochberg, Y. (2020). Risk Perception Through the Lens of Politics in the Time of the COVID-19 Pandemic. National Bureau of Economic Research. https://doi.org/10.3386/w27008.

Becker, C. (1992). Living and relating: An introduction to phenomenology. Thousand Oaks, CA: Sage Publications, Inc.

Berg, B. L., \& Lune, H. (2017). Qualitative research methods for social sciences (9th ed.). Boston, MA: Pearson Education Ltd.

Borup, J., \& Evmenova, A. S. (2019). The effectiveness of professional development in overcoming obstacles to effective online instruction in a college of education. Online Learning, 23(2), 1-20. http://dx.doi.org/10.24059/olj.v23i2.1468.

Boyd, C.O. (2001). Phenomenology the Method. In P.L. Munhall (Ed.), Nursing research: A qualitative Perspective $\left(3^{\text {rd }}\right.$. ed., pp. 93-122). Sudbury, MA: Jones and Barlett.

Castroverde, F. \& Acala, M. (2021). Modular distance learning modality: Challenges of teachers in teaching amid the Covid-19 pandemic. International Journal of Research Studies in Education, Vol. 10, No. 15, pp. 7 - 15. http://dx.doi.org/10.5861/ijrse.2021.602.

Chinazzi, M., Davis, J. T., Ajelli, M., Gioannini, C., Litvinova, M., Merler, S., .. Vespignani, A. (2020). The effect of travel restrictions on the spread of the 2019 novel coronavirus (COVID-19) Outbreak. Science, 368(6489), 395. http://dx.doi.org/10.1126/science.aba9757.

Creswell, J.W. (2018). Qualitative Inquiry and Research Design: Choosing among Five Traditions (6 $6^{\text {th }}$ Edition). Thousand Oaks, CA: Sage Publications.

Creswell, J.W., \& Plano Clark, V.L. (2018). Designing and Conducting Mixed Methods Research (3 ${ }^{\text {rd }}$ Ed.). Thousand Oaks, CA: Sage Publications, Inc.

DepEd. (2020a). School Effectiveness Toolkit for the Implementation of the Basic Education Learning Continuity Plan in Light of the COVID-19 Public Health Emergency. DepEd Complex, Meralco Ave., Pasig City.

DepEd. (2020b). Adoption of the Basic Education Learning Continuity Plan for School Year 2020-2021 in Light of the COVID-19 Public Health Emergency. In DepEd Order No. 012, s. 2020. DepEd Complex, Meralco Ave., Pasig City.

DepEd. (2020c). Readiness Assessment Checklist for Learning Delivery Modalities in the Learning Continuity Plan of Private Schools. In DepEd Order No. 013, s. 2020. DepEd Complex, Meralco Ave., Pasig City.

Enitan, S.S., Ibeh, I.N., Oluremi, A.S., Olayanju, A.O., \& Itodo, G.E. (2020). The 2019 Novel Coronavirus Outbreak: Current Crises, Controversies and Global Strategies to Prevent a Pandemic. International Journal for Pathogen Research, Vol. 4, Issue 1, pp. 1-16. http://dx.doi.org/10.9734/IJPR/2020/v4i130099.

Fernandes, N. (2020). Economic Effects of Coronavirus Outbreak (COVID-19) on the World Economy. http://dx.doi.org/10.2139/ssrn.3557504.

Fraenkel, J.R., Wallen, N.E. \& Hyun, H.H. (2013). How to design and evaluate research in education (8 ${ }^{\text {th }}$ Edition). New York, USA: McGraw-Hill Education.

Groenewald, T. (2004). A Phenomenological Research Design Illustrated. International Journal of Qualitative Methods, 3(1). Retrieved from https://doi.org/10.1177/160940690400300104.

Habibi, R., Burci, G.L., De Campos, T.C., Chirwa, D., Cina, M., Dagron, S., ... Hoffman, S. (2020). Do not violate the International Health Regulations during the COVID-19 Outbreak. The Lancet, 395 (10225). http://dx.doi.org/10.1016/S0140-6736(20)30373-1.

Hammersley, M. (2003). Conversation Analysis and Discourse Analysis: Methods or Paradigms? Discourse \& Society, 14(6), 751-781. Retrieved from https://doi.org/10.1177/09579265030146004.

Hanson, D., Maushak, N.J., Schlosser, C.A., Anderson, M.L., Sorenson, C., \& Simonson, M. (1997). Distance Education: Review of the Literature (2 ${ }^{\text {nd }}$ Ed.). Washington, DC: Association for Educational Communications and Technology. 
Hashemi, A. \& Sina, K. (2020). The Effects of Using Blended Learning in Teaching and Learning English: A Review of Literature. The Eurasia Proceedings of Educational \& Social Sciences (EPESS), Vol. 18, pp. 173-179. Retrieved from https://files.eric.ed.gov/fulltext/ED614699.pdf.

Heath, S., \& Shine, B. (2021). Teaching Techniques to Facilitate Time Management in Remote and Online Teaching. Journal of Teaching and Learning with Technology, 10(1). Retrieved from https://scholarworks.iu.edu/journals/index.php/jottl/article/view/31370.

Henaku, E.A. (2020). COVID-19: Online Learning Experience of College Students: The Case of Ghana. International Journal of Multidisciplinary Sciences and Advanced Technology, Vol. 1, Special Issue No. 2, pp. 54 - 62. https://www.researchgate.net/publication/342586709.

Jones, J. (2019). The Implications of Blended Learning in Today's Classroom: A Look into the History, Views, Impacts, and Research. Master's Theses \& Capstone Projects, Northwestern College, Iowa. Retrieved from https://bit.ly/3Kp4goa.

Langdridge, D. (2007). Phenomenological psychology: Theory, research and method. Harlow, Pearson Prentice Hall.

Lee, J. \& Lin, L. (2009) Chapter V, Applying Constructivism to Online Learning: A New Instructional Design Map. In, C. Payne (ed.), Information Technology and Constructivism in Higher Education: Progressive Learning Frameworks, pp. 58-73. Hershey, PA: Information Science Reference.

Moore, M.G. (1983). The Individual Adult Learner. In M. Tight (Ed.), Adult Learning and Education. London: Croom Helm.

Morrissey, G. \& Higgs, J. (2006). Phenomenological Research and Adolescent Female Sexuality: Discoveries and Applications. The Qualitative Report, Vol. 11, No. 1. Retrieved from https://bit.ly/38VbJt1.

Rasmitadila, Aliyyah, R. R., Rachmadtullah, R., Samsudin, A., Syaodih, E., Nurtanto, M., \& Tambunan, A. R. S. (2020). The Perceptions of primary school teachers of online learning during the COVID-19 Pandemic period: A case study in Indonesia. Journal of Ethnic and Cultural Studies, 7(2), 90-109. http://dx.doi.org/10.29333/ejecs/388

Reimers, F., Schleicher, A., Saavedra, J. \& Tuominen, S. (2020). Supporting the continuation of teaching and learning during the COVID-19 Pandemic: Annotated resources for online learning. Organization for Economic Cooperation and Development (OECD). https://www.oecd.org/education/Supporting-the-continuation-ofteaching-and-learning-during-the-COVID-19-pandemic.pdf

San Jose, A., Concepcion, M.G.R. \& San Jose, B.R. (2021). Mothers as Teachers: The New Role of Mothers in the New Normal. Electronic copy available at: https://ssrn.com/abstract=3926482.

Toquero, C.M. (2020). Challenges and Opportunities for Higher Education amid the COVID-19 Pandemic: The Philippine Context. Pedagogical Research, 5(4). https://doi.org/10.29333/pr/7947.

Tria, J.Z. (2020). The COVID-19 Pandemic through the Lens of Education in the Philippines: The New Normal. International Journal of Pedagogical Development and Lifelong Learning, 1(1), ep2001. https://doi.org/10.30935/ijpdl1/8311.

United Nations. (2020). Policy Brief: The Impact of COVID-19 on Children. Retrieved from https://www.un.org/sites/un2.un.org/files/policy_brief_on_covid_impact_on_children_16_april_2020.pdf.

Viner, R.M., Russell, S.J., Croker, H., Packer, J., Ward, J., Stansfield, C., ... Booy, R. (2020). School Closure and Management Practices during Coronavirus Outbreaks including COVID-19: A Rapid Systematic Review. The Lancet Child \& Adolescent Health, 4(5), 397-404. https://doi.org/10.1016/S2352-4642(20)30095-X.

Weaver, J.L. \& Swank, J.M. (2021). Parents' Lived Experiences With the COVID-19 Pandemic. The Family Journal: Counseling and Therapy for Couples and Families, Vol. 29(2) 136-142. DOI: https://doi.org/10.1177/1066480720969194.

WHO. (2020a). $R \&$ D Blueprint and COVID-19. Retrieved from https://bit.ly/374Aa7C.

WHO. (2020b). Coronavirus Disease 2019 (COVID-19) Situation Report - 51. World Health Organization. Retrieved from https://bit.ly/3oGJ2GS.

Yarovaya, O., Yarovaya, L. \& Bogatskaya, E. (2020). Distance learning during coronavirus: problems and solutions. E3S Web of Conferences 210, 18051. Retrieved from https://doi.org/10.1051/e3sconf/202021018051

Yüksel, P. \& Yıldırım, S. (2015). Theoretical Frameworks, Methods, and Procedures for Conducting Phenomenological Studies in Educational Settings. Turkish Online Journal of Qualitative Inquiry, 6 (1), 1-20. https://doi.org/10.17569/tojqi.59813. 